\title{
PENGARUH PEMBERIAN HUKUMAN TERHADAP KEDISIPLINAN PESERTA DIDIK
}

\author{
Nurlita Maulida $^{a)}$, Mira Mirawati $^{\left.a^{*}\right)}$, Wawan Syahiril Anwar ${ }^{a)}$ \\ ${ }^{a)}$ Universitas Pakuan, Bogor, Indonesia \\ ${ }^{*}$ e-mail korespondensi : mira.mirawati@unpak.ac.id
}

\begin{abstract}
Abstrak. Penelitian ini dengan menggunakan desain penelitian kuantitatif jenis kausal. Tujuan dalam penelitian adalah untuk mengetahui pengaruh pemberian hukuman terhadap kedisiplinan peserta didik. Penelitian ini dilaksanakan di Sekolah Dasar Negeri Panaragan 1 di kelas V semester ganjil tahun pelajaran 2019/2020. Populasi dalam penelitian berjumlah 108 peserta didik dan sampel yang diambil sebanyak 52 peserta didik diperoleh menggunakan rumus Taro Yamane. Hasil penelitian menunjukkan bahwa terdapat pengaruh pemberian hukuman terhadap kedisiplinan peserta didik, ditunjukkan dengan analisis statistik yang menghasilkan koefisien korelasi sebesar 0,485. Teknik analisis data dengan analisis regresi dan koefisien jalur menghasilkan suatu model keberpengaruhan yang dinyatakan dalam bentuk persamaan regresi yaitu $\hat{\mathrm{Y}}=63,07+0,35 \mathrm{X}$, dengan harga Fhitung sebesar 15,34 lebih besar dari Ftabel dengan taraf nyata 0,05 sebesar 4,03 dan kontribusi berdasarkan hasil penelitian sebesar 23,52\% sedangkan 76,48\% dipengaruhi oleh faktor lain, maka dapat disimpulkan bahwa terdapat pengaruh positif dan signifikan pemberian hukuman terhadap kedisiplinan peserta didik kelas V Sekolah Dasar Negeri Panaragan 1 Semester Ganjil tahun pelajaran 2019/2020
\end{abstract}

Kata Kunci: pemberian hukuman; kedisiplinan; peserta didik

\section{THE EFFECT OF PUNISHMENT OF THE DISCIPLINE OF STUDENTS}

Abstract. This research uses a causal quantitative research design. The purpose of this research is to determine the effect of punishment on the discipline of students. This research was conducted at Panaragan 1 Primary School in class V odd semester $2019 / 2020$ school year. The population in the study amounted to 108 students and samples taken as many as 52 students were obtained using the Taro Yamane formula. The results showed that there was an effect of giving penalties on student discipline, indicated by statistical analysis which resulted in a correlation coefficient of 0.485 . Data analysis techniques with regression analysis and path coefficients produce a model of influence expressed in the form of a regression equation that is $\hat{Y}=63.07+0.35 \mathrm{X}$, with a Fcount value of 15.34 greater than Ftable with a significance level of 0.05 of 4, 03 and the contribution based on the results of the study amounted to $23.52 \%$ while $76.48 \%$ is influenced by other factors, it can be concluded that there is a positive and significant effect on the discipline of the fifth grade students of Panaragan State Elementary School 1 Odd Semester in the 2019/2020 school year

Keywords: giving punishment; discipline; students.

\section{PENDAHULUAN}

Pendidikan merupakan hal yang sangat penting dalam pembentukan karakter manusia. Pendidikan bertujuan untuk mengembangkan potensi peserta didik agar menjadi manusia yang beriman dan bertakwa kepada Tuhan Yang Maha Esa, berakhlak mulia, sehat, berilmu, cakap, kreatif, mandiri, dan bertanggung jawab. Dalam mewujudkan tujuan pendidikan tersebut dibutuhkan sosok yang mampu menjadi tumpuan proses pendidikan itu berlangsung yaitu pendidik.

Peran pendidik sangat penting dalam dunia pendidikan, karena tidak hanya bertugas dalam mengajar tetapi juga sebagai pelatih, pembimbing, dan manager kelas. Hal ini sudah sesuai dengan fungsi dari peran pendidik tersebut. Pendidik juga tidak hanya memiliki kemampuan intelektual saja tetapi juga memiliki kemampuan emosional dan spiritual yang diperlukan untuk menanamkan nilai karakter kepada peserta didik, salah satunya menanamkan karakter disiplin.

Berdasarkan hasil observasi yang telah peneliti laksanakan di kelas V Sekolah Dasar Negeri Panaragan 1 Kota Bogor, dapat diketahui jumlah peserta didik kelas V adalah 108 peserta didik yang terdiri dari 3 kelas. Pada masing-masing kelas masih terdapat peserta didik yang kurang disiplin sekitar 20\% - 30\%, diantaranya peserta didik masih ribut ketika proses pembelajaran, tidak memakai baju seragam yang sesuai, tidak memakai atribut lengkap saat upacara, tidak memperhatikan pembelajaran, dan telat mengumpulkan tugas. Hal ini menggambarkan peserta didik tidak disiplin dalam mematuhi aturan tata tertib di sekolah.

Penyebab permasalahan kedisiplinan peserta didik ini yaitu peserta didik kurang memiliki kesadaran terhadap kedisiplinan, peserta didik masih kurang memahami tentang pentingnya kedisiplinan selama proses pembelajaran, peserta didik tidak membiasakan sikap disiplin dalam kehidupannya, guru kurang menanamkan karakter disiplin kepada peserta didik, guru kurang memberikan perhatian kepada peserta didik yang melakukan pelanggaran di kelas. Hal ini termasuk bagaimana anak dapat memilih baik tidanya suatu hal. Adapun faktor lain yang berpengaruh yaitu tidak adanya reward kepada peserta didik yang telah melaksanakan disiplin dan tidak adanyanya peraturan ketika proses pembelajaran di sekolah. 
Upaya mengatasi permasalahan kedisiplinan peserta didik dapat dilakukan melalui pemberian hukuman. Pemberian hukuman bertujuan agar peserta didik dapat merubah perilakunya kearah yang lebih baik. Hukuman membuat peserta didik lebih patuh terhadap suatu peraturan, dan peserta didik akan merasa takut untuk melakukan pelanggaran. Hukuman juga dapat mengajari peserta didik terhadap apa yang tidak boleh dilakukan.

Hukuman dapat menjadi alat pengendali perilaku yang masih menyimpang pada peserta didik, hal ini dilakukan agar peserta didik berhenti dan tidak melakukan perbuatan yang salah, sehingga pemberian hukuman ini dapat menjadi alat yang efektif dalam meningkatkan kedisiplinan peserta didik agar tercapainya tujuan pendidikan sesuai dengan apa yang diharapkan.

Disiplin merupakan suatu sikap yang sangat dibutuhkan dalam pendidikan, karena dapat membantu suatu kegiatan belajar mengajar berjalan dengan lancar. Disiplin seringkali berkaitan dengan tata tertib atau peraturan yang membuat seseorang harus patuh pada peraturan tersebut.

Sebagaimana yang dikemukakan oleh Imron [1] yang menyatakan bahwa disiplin adalah suatu keadaan dimana sesuatu itu berada dalam keadaan tertib, teratur dan semestinya, serta tidak ada suatu pelanggaran-pelangaran baik secara langsung atau tidak langsung.

Disiplin juga terbagi berdasarkan ruang lingkupnya yang dikemukakan oleh Haryono [2] bahwa disiplin terbagi menjadi tiga macam, yaitu: (1) Disiplin diri yaitu apabila peraturan-peraturan atau ketentuan-ketentuan itu hanya berlaku bagi diri seseorang. Disiplin ini hanya dilakukan personal yang mengikat dirinya sendiri. Misalnya, disiplin belajar, disiplin bekerja, dan disiplin beribadah. (2) Disiplin sosial adalah apabila ketentuan-ketentuan atau peraturanperaturan itu harus dipatuhi oleh orang banyak atau masyarakat. Misalnya, disiplin lalu lintas, dan disiplin menghadiri rapat. (3) Disiplin nasional tidak lain dari kesadaran nasional akan tatanan masyarakat yang berlaku serta ketaatan kepada peraturan perundang-undangan. Memasyarakatkan kesadaran hukum merupakan salah satu upaya menegakkan disiplin nasional. Menjelaskan tentang hak dan kewajiban setiap warga, juga termasuk salah satu langkah menegakkan disiplin nasional. Nilai disiplin menjadi motor penggerak terimplementasinya nilai-nilai karakter yang lain [3].

Adapun unsur-unsur disiplin dikemukakan oleh Shofiyati [4] yang menyatakan ada empat unsur-unsur disiplin, yaitu: (1) Peraturan sebagai pedoman perilaku, berpengaruh terhadap kepribadian seseorang untuk melakukan sesuatu dengan baik. (2) Konsistensi dalam peraturan, sikap konsistensi sangat dibutuhkan dalam memotivasi dan mendorong siswa melakukan perilaku yang baik yang diperlukan adalah ketegasan dalam melaksanakan peraturan. (3) Hukuman untuk pelanggaran, hukuman bisa menanamkan rasa takut, kemarahan, dan penghindaran. (4) Penghargaan untuk perilaku yang baik, membuat anak mengerti apakah perilakunya dapat diterima atau tidak.

Menurut Sumantri [5] tujuan disiplin adalah siswa belajar hidup dengan pembiasaan yang baik dan bermanfaat bagi dirinya dan lingkungannya. Belajar setiap hari harus secara teratur hanya mungkin dijalankan kalau siswa mempunyai disiplin untuk mentaati rencana yang dibuatnya. Sedangkan faktor-faktor kurang disiplinnya peserta didik dikemukakan oleh Sri [6] yang menyatakan ada beberapa faktor peserta didik kurang disiplin di sekolah, antara lain: (1) Sekolah kurang menerapkan disiplin, sekolah yang kurang menerapkan disiplin biasanya kurang bertanggung jawab karena siswa menganggap tidak melaksanakan tugas tidak dikenakan sanksi dan tidak dimarahi guru. (2) Teman bergaul, anak yang bergaul dengan anak yang kurang baik perilakunya akan berpengaruh terhadap anak yang diajak berinteraksi sehari-hari. (3) Cara hidup di lingkungan anak tinggal, anak yang tinggal di lingkungan hidup yang kurang baik akan cenderung bersikap dan berperilaku kurang baik. (4) Sikap orang tua, anak yang dimanjakan oleh orangtuanya akan cenderung kurang bertanggung jawab dan takut menghadapi tantangan dan kesulitan, sebaliknya anak yang sikap orangtuanya otoriter, anak akan menjadi penakut dan tidak berani mengambil keputusan dalam bertindak. (5) Keluarga yang tidak harmonis, anak yang tumbuh dikeluarga yang kurang harmonis biasanya akan selalu menggangu teman dan sikapnya kurang disiplin. (6) Latar belakang kebiasaan dan budaya, budaya dan tingkat pendidikan orangtuanya akan berpengaruh terhadap sikap dan perilaku anak. Anak yang hidup di keluarga yang baik dan tingkat pendidikan orangtuanya bagus akan cenderung berperilaku yang baik pula. Aqib dalam Pertiwi [6] mengatakan bahwa Pendidikan karakter harus dapat menanamkan suatu kebiasaan tentang segala hal yang akan dipilih untuk dilakukan oleh setiap anaknya.

Berdasarkan uraian di atas, dapat disintesiskan bahwa kedisiplinan peserta didik adalah suatu keadaan yang membentuk sikap seseorang untuk mematuhi tata tertib yang telah ditetapkan, yang akan terbentuk jika memiliki unsur ketaatan, keteraturan, ketertiban, dan kosistensi sehingga peserta didik akan berperilaku sesuai dengan peraturan atas kesadaran dirinya sendiri.

Dalam dunia pendidikan juga hukuman kerap kali digunakan oleh guru kepada peserta didiknya, sebagaimana yang diungkapkan oleh Wiyani [7] bahwa hukuman dapat didefinisikan sebagai upaya guru secara sadar dan disengaja untuk memberikan sesuatu yang tidak menyenangkan kepada peserta didiknya yang melanggar tata tertib kelas agar ia tidak mengulanginya lagi.

Ada berbagai jenis hukuman sebagaimana yang dikemukakan oleh Febianti [8] yang menyatakan bahwa punishment (hukuman) terbagi menjadi empat macam, yaitu : (1) Punishment dengan isyarat, punishment semacam ini dijatuhkan kepada sesama atau siswa dengan cara memberi isyarat melalui mimik dan juga pantomimik. Misalnya dengan mata, raut muka, dan bahkan ganjaran anggota tubuh. (2) Punishment dengan perkataan, punishment dengan perkataan dimaksudkan sebagai punishment yang dijatuhkan kepada siswa melalui perkataan. (3) Punishment dengan perbuatan, punishment ini diberikan kepada siswa dengan memberikan tugas-tugas terhadap siswa yang bersalah. Misalnya dengan memberi pekerjaan rumah yang jumlahnya 
tidak sedikit (4) Punishment (hukuman) badan, punishment (hukuman) badan adalah punishment yang dijatuhkan dengan cara menyakiti badan siswa baik dengan alat atau tidak misalnya memukul, mencubit, dan lain sebagainya.

Adapun tujuan hukuman yang di kemukakan oleh Maghfiroh [9] bahwa hukuman diberikan bertujuan menghentikan anak untuk berperilaku menyimpang dan tidak sesuai dengan aturan atau tata nilai yang ada, atau tidak sesuai dengan harapan orang tua, namun dengan memberikan sesuatu hal yang menyakitkan ataupun tidak menyenangkan bagi si anak.

Hukuman sangat penting diterapkan dalam kehidupan, maka ada beberapa faktor penyebab hukuman diberikan kepada seseorang, sebagaimana yang dikemukakan oleh Selan [10] bahwa faktor-faktor penyebab penerapan hukuman dalam dunia pendidikan adalah dari faktor guru itu sendiri,dari siswa, dari keluarga dan dari lingkungan.

Terdapat prinsip-prinsip dalam pemberian hukuman yang dikemukakan oleh Kompri [11] adalah sebagai berikut : (1) Kepercayaan terlebih dahulu kemudian hukuman, (2) Hukuman distandarkan pada perilaku, (3) Menghukum tanpa emosi,. (4) Hukuman sudah disepakati,. (5) Tahapan pemberian hukuman, dalam memberikan hukuman tentu harus melalui beberapa tahapan, mulai dari yang teringan hingga akhirnya jadi yang terberat.

Berdasarkan uraian di atas, dapat disintesiskan bahwa pemberian hukuman adalah suatu cara yang diberikan kepada seseorang yang telah melakukan pelanggaran atau kesalahan yang dapat memberikan efek jera kepadanya dengan memberikan teguran, larangan, peringatan, sanksi sehingga dapat menyadarkannya agar tidak mengulangi kesalahan lagi dan dapat memperbaiki perilakunya kearah yang lebih baik.

\section{METODE PENELITIAN}

Jenis penelitian ini adalah penelitian kuantitatif, yakni penelitian yang menganalisis data-data secara kuantitatif/ statistik, dengan tujuan untuk menguji hipotesis yang telah ditetapkan kemudian menginterprestasikan hasil analisis tersebut untuk memperoleh kesimpulan. Penelitian kausal ini dilaksanakan pada peserta didik kelas V di Sekolah Dasar Negeri Panaragan 1 Kota Bogor Pada Semester Ganjil Tahun Pelajaran 2019/2020. Populasi dalam penelitian ini adalah seluruh peserta didik kelas V di Sekolah Dasar Negeri Panaragan 1 Kota Bogor Tahun Pelajaran 2019/2020 yang berjumlah 108 peserta didik. Pengambilan sampel penelitian menggunakan rumus Taro Yamane yang menghasilkan sebanyak 52 peserta didik sebagai sampel penelitian.

Penelitian ini terdiri dari dua variabel yaitu pemberian hukuman sebagai variabel bebas (X) dan kedisiplinan peserta didik sebagai variabel terikat (Y) Teknik pengumpulan data merupakan teknik atau cara yang digunakan oleh peneliti untuk memperoleh data yang tepat untuk kemudian dilanjutkan dengan menyusun alat pembantunya yang disebut instrumen [12]. Dalam penelitian ini menggunakan metode angket (kuisioner) yang menggunakan skala likert untuk mengumpulkan data tentang pemberian hukuman dan kedisiplinan peserta didik

Sebelum di uji coba, instrumen terlebih dahulu diuji validitas dan realibilitasnya. Instrumen menggunakan rumus Pearson Product Moment dan rumus Alfa Cronbach. Data yang sudah terkumpul lalu melalui tahap uji prasyarat analisis yang terdiri dari uji normalitas, uji homogenitas, uji regresi linier sederhana dan uji linearitas regresi sebelum akhirnya dilakukan uji hipotesis untuk mengetahui besaran koefisien determinasinya.

\section{HASIL DAN PEMBAHASAN}

Deskripsi data hasil penelitian dikelompokkan menjadi dua bagian, yang terdiri dari: data variabel terikat, yaitu Kedisiplinan Peserta Didik (Y), dan data variabel bebas yaitu Pemberian Hukuman (X).

Berdasarkan hasil perhitungan uji homogenitas variabel pemberian hukuman dan kedisiplinan peserta didik diperoleh $F_{\text {hitung }}$ sebesar 1,381 untuk sampel 52 dan taraf signifikan $\alpha(0,05)$ diperoleh $F_{\text {tabel }}$ sebesar 4,034. Jika $\mathrm{F}_{\text {hitung }}<\mathrm{F}_{\text {tabel }}$ berarti homogen dan jika $\mathrm{F}_{\text {hitung }}>\mathrm{F}_{\text {tabel }}$ tidak homogen. Hal ini menunjukkan skor pada variabel pemberian hukuman dan kedisiplinan peserta didik memiliki varians yang sama sehingga kedua skor berasal dari populasi yang homogen.

Pengaruh antara variabel pemberian hukuman $(\mathrm{X})$ terhadap kedisiplinan peserta didik (Y) yang berdasarkan hasil uji perhitungan signifikansi dan dinyatakan dalam bentuk persamaan regresi yaitu $\hat{\mathrm{Y}}=\mathrm{a}+\mathrm{bx}$. Setelah melalui perhitungan untuk mencari a dan $b$, bentuk persamaan regresi berubah menjadi $\hat{Y}=63,07+0,35 X$. Data mengenai persamaan regresi dapat dilihat pada diagram pancar, sebagai berikut :

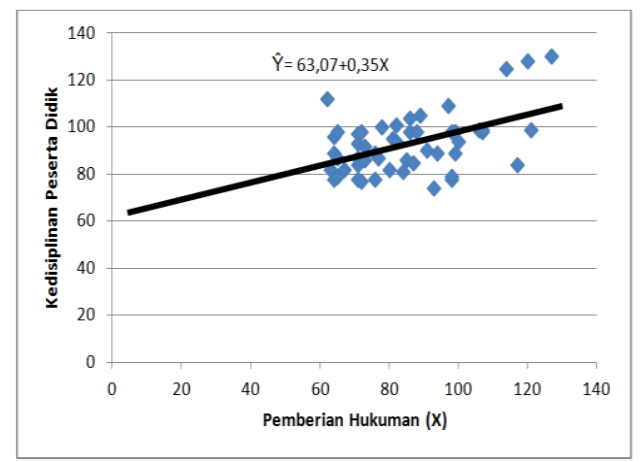

Gambar 1. Diagram Pencar Pengaruh Variabel X dengan Y

Hasil perhitungan analisis persamaan regresi pada gambar diagram pancar di atas menunjukkan keeratan antara data variabel $\mathrm{X}$ dan $\mathrm{Y}$ dimana setiap kenaikan satu unit variabel (X) pemberian hukuman akan menyebabkan peningkatan pada variabel kedisiplinan peserta didik (Y) sebesar 0,35 unit. Kebenaran dari hasil regresi tersebut digunakan untuk menguji hipotesis mengenai ada tidaknya pengaruh positif pemberian hukuman (X) terhadap kedisiplinan peserta didik (Y). Uji signifikansi regresi 
digunakan untuk mengetahui apakah variabel $\mathrm{X}$ berpengaruh secara signifikan terhadap variabel $\mathrm{Y}$ dengan syarat hipotesis teruji apabila $F_{\text {hitung }}>F_{\text {tabel }}$. Hasilnya dapat dilihat pada tabel berikut ini:

Tabel 1. ANAVA untuk Uji Signifikan dengan Persamaan

\begin{tabular}{|c|c|c|c|c|c|c|c|}
\hline$\frac{\text { Sumber }}{\text { Varian }}$ & $\begin{array}{l}d k \\
\text { (df) }\end{array}$ & JK (SS) & RJK & \multirow{2}{*}{$F_{\text {hitung }}$} & \multicolumn{2}{|c|}{$F_{\text {tabel }}$} & \multirow{2}{*}{ Kesimpulan } \\
\hline Total & 52 & 457622 & 457622 & & 0,05 & 0,01 & \\
\hline Regresi (a) & 1 & 449,748 & 449,748 & & & & \\
\hline$\frac{\text { Regresi }}{(\mathrm{b} \mid \mathrm{a})}$ & 1 & 1849,05 & 1849,05 & 15,344 & 4,03 & 7,17 & $\begin{array}{l}\text { Sangat } \\
\text { Signifikan }\end{array}$ \\
\hline Residu & 50 & 6024,95 & 120,499 & & & & \\
\hline
\end{tabular}

Berdasarkan hasil perhitungan uji signifikansi regresi diperoleh $\mathrm{F}_{\text {hitung }}=15,344$ dengan $\mathrm{F}_{\text {tabel }}\left(\alpha_{=0,05)}=4,03\right.$ dan $\mathrm{F}_{\text {tabel }}$ $\left(\alpha_{=0,01)}=7,17\right.$. Maka $\mathrm{F}_{\text {hitung }}>\mathrm{F}_{\text {tabel }}\left(\alpha_{=0,01)}>\mathrm{F}_{\text {tabel }}\left(\alpha_{=0,05)}=\right.\right.$ $15,344>7,17>4,03$. Dengan demikian bahwa nilai $\mathrm{F}_{\text {hitung }}>$ $F_{\text {tabel }}$ antara pemberian hukuman dengan kedisiplinan peserta didik yang ditunjukkan dengan persamaan regresi yaitu sangat signifikan.

Tabel 2. ANAVA Uji Linearitas Variabel X dan Y

\begin{tabular}{|c|c|c|c|c|c|c|c|}
\hline $\begin{array}{l}\frac{\text { Sumber }}{\text { Varian }} \\
\end{array}$ & $\begin{array}{l}\mathrm{dk} \\
\text { (df) }\end{array}$ & JK (SS) & RJK & \multirow{2}{*}{$F_{\text {hitung }}$} & \multicolumn{2}{|c|}{$F_{\text {tabel }}$} & \multirow{2}{*}{$\frac{\text { Kesim }}{\text { pulan }}$} \\
\hline Total & 52 & 457622 & 457622 & & 0,05 & 0,01 & \\
\hline $\begin{array}{l}\text { Tuna } \\
\text { Cocok }\end{array}$ & 31 & $-431861,4$ & $-13931,012$ & & & & \\
\hline Galat & 19 & 437886,35 & 23046,65 & & & & \\
\hline
\end{tabular}

Berdasarkan pengujian linearitas regresi pemberian hukuman (X) dengan kedisiplinan peserta didik (Y) diperoleh $\mathrm{F}_{\text {hitung }}=0,005$ sedangkan $\mathrm{F}_{\text {tabel }(0,05)}=2,06$ dan $\mathrm{F}_{\text {tabel }(0,01)}=2,83$ dengan dk pembilang $(\mathrm{K}-2)=31 \mathrm{dan} \mathrm{dk}$ penyebut $(n-K)=19$. Dengan demikian $F_{\text {hitung }}<F_{\text {tabel }}(\alpha=0,05)$ $\left.<\mathrm{F}_{\text {tabel }} \alpha=0,01\right)=0,005<2,06<2,83$ menandakan bahwa hipotesis linier diterima. Hal ini menunjukkan adanya pengaruh yang linier antara pemberian hukuman dengan kedisiplinan peserta didik.

Setelah itu dilakukan uji signifikansi koefisien jalur dengan uji t. Kriteria pengujian signifikansi koefisien jalur sama dengan koefisien korelasi yaitu jika $t_{\text {hitung }}>t_{\text {tabel }}$, maka koefisien jalur dinyatakan signifikan. Berdasarkan hasil perhitungan diperoleh $\mathrm{t}_{\text {hitung }}=3,931$ dengan $\mathrm{t}_{\text {tabel }}=2,008$ dengan demikian $t_{\text {hitung }}>t_{\text {tabel }}=3,931>2,008$ yang berarti koefisien jalur pemberian hukuman dengan kedisiplinan peserta didik bersifat signifikan, sehingga dapat disimpulkan bahwa terdapat pengaruh positif dan signifikan antara pemberian hukuman terhadap kedisiplinan peserta didik.

Berdasarkan nilai koefisiensi korelasi $\left(r_{x y}\right)$ terhadap pemberian hukuman (X) dengan kedisiplinan peserta didik (Y) hasilnya $r_{x y}=0,485$. Untuk melihat tingkat hubungannya dapat dikonsultasikan dengan tabel interpretasi yang hasilnya menunjukkan koefisien korelasi 0,485 berada pada interval koefisien $0,400-0,599$, yang berati tingkat hubungannya sedang. Untuk mengetahui tingkat hubungan antara variabel dapat dilihat pada tabel di bawah ini.

Tabel 3. Interpretasi Koefisien Korelasi Product Moment

\begin{tabular}{|c|c|}
\hline Interval Koefisien & Tingkat Hubungan \\
\hline $0,000-0,199$ & Sangat Rendah \\
\hline $0,200-0,399$ & Rendah \\
\hline $0,400-0,599$ & Sedang \\
\hline $0,600-0,799$ & Kuat \\
\hline $0,800-1,000$ & Sangat Kuat \\
\hline
\end{tabular}

Berdasarkan nilai koefisiensi determinasi $\left(\mathrm{r}^{2}\right)$ antara pemberian hukuman dengan kedisiplinan peserta didik didapatkan hasil 0,2352. Hal ini berarti memiliki kontribusi sebesar 23,52\% terhadap kedisiplinan peserta didik dan $76,48 \%$ dipengaruhi oleh faktor lain.

Pengujian hipotesis dengan menggunakan uji korelasi Product Moment Pearson, hasil penelitian menunjukkan adanya pengaruh yang fungsional antara Pemberian Hukuman dengan Kedisiplinan Peserta Didik secara analisis statistik yang dapat ditunjukan dengan persamaan regresi $\hat{Y}=63,07+0,35 X$. Selanjutnya uji signifikansi koefisien korelasi diperoleh $t_{\text {hitung }}=3,931$ dengan derajat kebebasan (dk) 50, maka diperoleh $\mathrm{t}_{\text {tabel }(} \alpha_{=0,05)}=$ 2,008 sehingga hasil $\mathrm{t}_{\text {hitung }}=3,931>\mathrm{t}_{\text {tabel }}=2,008$ menunjukkan bahwa terdapat pengaruh positif antara pemberian hukuman $(\mathrm{X})$ terhadap kedisiplinan peserta didik (Y).

Kekuatan pengaruh pemberian hukuman terhadap kedisiplinan peserta didik menunjukkan nilai koefisien korelasi sebesar $r=0,485$ dengan harga koefisien korelasi yang sedang. Besar kontribusi yang ditunjukkan oleh koefisien korelasi $\mathrm{r}^{2}=0,2352$ atau $23,52 \%$. Hal ini dapat diartikan bahwa Pemberian Hukuman berperan memberi kontribusi sebesar $23,52 \%$ terhadap kedisiplinan peserta didik, sedangkan $76,48 \%$ kedisiplinan peserta didik dipengaruhi faktor lain.

Hasil perhitungan tersebut didukung dengan hasil penelitian yang dilakukan oleh Hernawati [13] Menyimpulkan bahwa adanya korelasi yang cukup signifikan dari penerapan sanksi berjenjang di SDN Mekarwangi I (Variabel X) dengan kedisiplinan siswa di SDN Mekarwangi I (Variabel Y), dengan indeks koefisien 0,988. Adapun taraf pengaruh penerapan sanksi berjenjang terhadap kedisiplinan siswa memiliki pengaruh sebesar $10 \%$, dan sisanya $90 \%$ menunjukkan faktor lain yang turut mempengaruhi kedisiplinan siswa di SDN Mekarwangi I Cihurip-Garut.

Penelitian lainnya dilakukan oleh Hadianti [14] Menyimpulkan bahwa terdapat pengaruh tata tertib sekolah sebesar 39\% terhadap kedisiplinan belajar siswa dan sisanya $61 \%$ faktor lain yang mempengaruhi kedisiplinan belajar siswa. Hasil penelitian ini didukung oleh teori yang dikemukakan Wiyani [7] bahwa hukuman merupakan upaya guru secara sadar dan disengaja untuk memberikan sesuatu yang tidak menyenangkan kepada peserta didiknya yang melanggar tata tertib kelas agar ia tidak mengulanginya lagi. 
Berdasarkan uraian diatas, menunjukkan terdapat pengaruh yang positif antara pemberian hukuman terhadap kedisiplinan peserta didik. Hal ini menunjukkan bahwa hipotesis penelitian dapat diterima karena pemberian hukuman memberikan kontribusi terhadap kedisiplinan peserta didik.

\section{SIMPULAN}

Berdasarkan hasil pengolahan data, hasil hipotesis dan pembahasan hasil penelitian, maka dapat disimpulkan bahwa pemberian hukuman dan kedisiplinan peserta didik menunjukkan adanya pengaruh yang positif dan signifikan. Hal ini ditunjukkan dari persamaan $\hat{Y}=63,07+0,35 X$, artinya setiap peningkatan 1 unit pemberian hukuman akan berpengaruh pada peningkatan kedisiplinan peserta didik sebesar 0,35 unit. Koefisien korelasinya sebesar 0,485 artinya pengaruh pemberian hukuman memiliki ikatan yang sedang terhadap kedisiplinan peserta didik, sedangkan kontribusi variabel pemberian hukuman dalam meningkatkan kedisiplinan peserta didik sebesar 0,2352 atau $23,52 \%$ sedangkan $76,48 \%$ dipengaruhi oleh faktor lain.

\section{REFERENSI}

[1] Imron, A. 2012. Manajemen Peserta Didik Berbasis Sekolah. Jakarta: Bumi Aksara.

[2] Haryono, S. 2016. "Pengaruh Kedisiplinan Siswa dan Motivasi Belajar Terhadap Prestasi Belajar Siswa Pada Mata Pelajaran Ekonomi". Faktor Jurnal Ilmiah Kependidikan. Vol 3,(3),h.261-274.

[3] R. Pertiwi and Y. Suchyadi, 2019. Implementasi Program Pendidikan Karakter Di Sekolah Dasar Negeri Lawanggintung 01 Kota Bogor," J. Pendidik. Pengajaran Guru Sekol. Dasar (JPPGuseda ), vol. 02, pp. 41-46, 2019.

[4] Shofiyati, S. 2012. Hidup Tertib. Jakarta: PT Balai Pustaka.

[5] Sumantri, B. 2010. "Pengaruh Disiplin Belajar Terhadap Prestasi Belajar Siswa Kelas IX SMK PGRI 4 Ngawi”. Jurnal Media Prestasi. Vol 6,(3),h.6

[6] Sri, M. 2016. Manajemen Sekolah. Jogjakarta: Diva Press..

[7] Wiyani, N.A. 2013. Manajemen Kelas Teori dan Aplikasi untuk Menciptakan Kelas yang Kondusif. Jogjakarta: Ar-Ruzz Media.

[8] Febianti, Y.N. 2018. "Peningkatan Motivasi Belajar Dengan Pemberian Reward And Punishment Yang Positif". Vol 6,(2),h.93-102.

[9] Maghfiroh, A. 2015. No Punisment No Worries : Menghapus Kekhawatiran Membangun Keberanian Dalam Pelajaran. Ponorogo: Unmuh Ponorogo Press.

[10] Selan, J. 2016. Pengaruh Penerapan Hukuman Terhadap Kemandirian Siswa. Vol 1,(1),h.23-25.

[11] Kompri. 2015. Motivasi Pembelajaran Perspektif Guru Dan Siswa. Bandung: PT Remaja Rosdakarya.
[12] Sugiyono. 2016. Metode Penelitian Pendidikan Pendekatan Kuantitatif, Kualitatif, dan $R \& D$. Bandung: Alfabeta.

[13] Hernawati, N. 2011. "Pengaruh Penerapan Sanksi Berjenjang Terhadap Kedisiplinan Siswa di SDN Mekarwangi I Kecamatan Cihurip Kabupaten Garut”. Jurnal Pendidikan Universitas Garut Fakultas Pendidikan dan Keguruan. Vol 2,(1),h.10-16.

[14] Hadianti, L.S. 2010. "Pengaruh Pelaksanaan Tata Tertib Sekolah Terhadap Kedisiplinan Belajar Siswa”. Jurnal Pendidikan Universitas Garut. Vol 2,(1),h.1-8. 